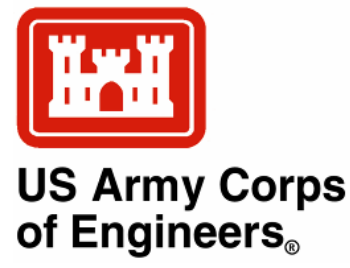

\title{
Use of Heating and Cooling Degree Days To Project Relative Changes in Heating and Cooling Costs in Response to Climate Change on Selected Army Installations
}

by Scott A. Tweddale

\section{INTRODUCTION}

Background: U.S. Army installation heating and cooling costs are a significant component of their overall energy costs. These heating and cooling costs will likely not remain static, but rather will change in response to climate change. Calculating heating and cooling degree days for future time periods based on projected mean temperatures from Global Circulation Models (GCMs) provides a rudimentary capability to estimate relative increases/decreases in heating and cooling costs on military installations. These potential changes in costs should be considered during the stationing analysis process, including large stationing efforts such as Base Realignment and Closure (BRAC). The Center for Army Analysis (CAA) often participates in large scale stationing analysis, and would therefore benefit from a capability to estimate projected increases/decreases in heating and cooling degree days, and indirectly, heating and cooling costs for U.S. Army installations.

Objective: The overall objective of this work was to document the data acquisition and analysis requirements for estimating future heating and cooling degree days, and (indirectly) relative future increases or decreases in heating and cooling costs for U.S. Army installations. Specifically, the objective was to develop and demonstrate methods to estimate projected heating and cooling degree days for one case study installation (Fort Benning, GA), nine GCMs, and four future dates $(2025,2035,2045,2055)$.

Approach: The approach taken in this work was to derive projected, spatially explicit climate data from nine representative GCMs and to calculate projected heating and cooling degree days for a U.S. Army installation case study (Fort Benning, GA). More specifically, a projected mean monthly temperature was calculated for four different epochs and mapped Continental United States (CONUS) wide. Mean monthly temperature for these epochs was used to estimate heating and cooling degree days for these same epochs. The installation boundary for Fort Benning, GA was then used to extract mean heating and cooling degree days for the installation and epoch by calculating the mean value for all pixels within the installation.

Scope: This work developed a methodology that could be applied CONUS-wide to estimate projected increases or decreases in heating and cooling degree days for any given location, including any U.S. Department of Defense (DOD) training installation.

Mode of technology transfer: The capabilities developed in this work will be provided to CAA to assist that organization with stationing analysis. 


\section{METHODOLOGY}

Global circulation models (GCMs): Under the direction of World Climate Research Program (WCRP), the U.S. Department of Energy established the Coupled Model Intercomparison Project (CMIP) as a standard experimental protocol for studying the output of GCMs. CMIP provides a community-based infrastructure in support of climate model diagnosis, validation, intercomparison, documentation, and data access. The current intercomparison of GCMs is CMIP Phase 5, or CMIP5 (http://pcmdi-cmip.|lnl.gov/index.html?submenuheader=0). A total of 62 GCMs in CMIP5 originate from a variety of international scientific organizations. Each GCM provides an estimate of daily and monthly precipitation and mean, maximum, and minimum temperature from 2006 to 2100. Projected mean monthly temperature for a subset of nine GCMs captured in CMIP5 were used in this analysis (Table 1). These GCMs were selected by a subject matter expert to provide a representative sample of all of the GCMs within CMIP5. Different greenhouse gas emission scenarios created by the scientific community are used by the GCMs to consider different possible concentrations in the atmosphere when projecting future climate. The emission scenarios are referred to as representative concentration pathway (RCP) emission scenarios (RCP2.6, RCP4.5, RCP6.0, and RCP8.5) with higher numbers representing higher emissions (Moss et al. 2010). This work used RCP scenarios 2.6 and 8.5 for each of the representative GCMs to calculate projected increases and decreases in heating and cooling degree days.

Table 1. GCMs used.

\begin{tabular}{|l|l|}
\hline Model & Institution/s \\
\hline BCC-CSM1-1-m & Beijing Climate Center, China Meteorological Administration \\
\hline CanESM2 & Canadian Centre for Climate Modeling and Analysis \\
\hline CCSM4 & National Center for Atmospheric Research \\
\hline CSIRO-Mk3-6-0 & $\begin{array}{l}\text { Commonwealth Scientific and Industrial Research Organization/ Queensland } \\
\text { Climate Change Centre of Excellence }\end{array}$ \\
\hline GFDL-ESM2G & Geophysical Fluid Dynamics Laboratory \\
\hline GISS-E2-R & $\begin{array}{l}\text { National Aeronautics and Space Administration (NASA) Goddard Institute for } \\
\text { Space Studies }\end{array}$ \\
\hline HadGEM2-ES & Met office Hadley Centre \\
\hline IPSL-CM5A-LR & Institut Pierre-Simon Laplace \\
\hline MPI-ESM-LR & Max Planck Institute for Meteorology (MPI-M) \\
\hline
\end{tabular}

GCMs typically have a spatial resolution of 1 to 4 degrees in longitude and latitude. However, this work used GCM data that had been downscaled using bias-corrected statistical downscaling (BCSD), resulting in 1/8-degree spatial resolution for CONUS (approx. 12X12 km).

U.S. Army installation projected mean monthly temperatures: As stated before, the goal of this work was to produce estimates of heating and cooling degree days for a case study installation (Fort Benning, GA), nine GCMs, two different RCP scenarios for each GCM, and four future dates $(2025,2035,2045$, and 2055). To characterize mean monthly temperature for these dates, a 10-year epoch around these dates (2020-2029, 2030-2039, 2040-2049, and 2050-2059) was selected for analysis. For example, the projected mean monthly temperature for January 2025 was calculated as the mean temperature for all Januarys between 2020 and 2029. 
To calculate projected cooling and heating degree days, projected mean monthly climate data (1/8degree BCSD-CMIP5 Climate Monthly Projections) for each of the nine GCMs listed above and for emission scenarios RCP2.6 and RCP8.5 was downloaded from:

http://gdo-dcp.ucllnl.org/downscaled cmip projections/dcplnterface.htm|\#Projections:\%20Complete\%20Archives

The original data format of the downloaded data was Network Common Data Form (NetCDF), which is a common, machine-independent file format for storing scientific data such as climate data. Using the R statistical package and using the NetCDF data as input, mean monthly temperature for the four different epochs mentioned above was calculated and mapped for each GCM and $\mathrm{RCP}$ emission scenario for the installation case study. More specifically, the R statistical package was used to extract all pixels within the Fort Benning, GA installation boundary to calculate mean monthly temperature for each epoch. Mean monthly temperature data were then used as input to heating and cooling degree day calculations described below to estimate projected heating and cooling degree days at Fort Benning, GA for each GCM, emission scenario, and epoch. CONUSwide estimates of projected heating and cooling degree days for different epochs and RCP scenarios have been calculated, along with several other climate-related variables, in a related report (Weatherly 2016)

Heating and cooling degree days: In this work, heating and cooling degree days based on projected climate data were used as a rudimentary method for estimating relative increases or decreases in heating and cooling costs on military installations. A degree day is defined as the difference in temperature between the outdoor mean temperature over a 24-hour period and given a base temperature. In this work, a base temperature of $65^{\circ} \mathrm{F}^{1}$ was used. Therefore, heating degree day and cooling degree day as used in this work are defined as (ASHRAE 2013):

- Cooling degree day base $65 F$ (CDD65). For any 1 day, when the mean temperature is more than $65^{\circ} \mathrm{F}$, there are as many degree days as degrees Fahrenheit temperature difference between the mean temperature for the day and $65^{\circ} \mathrm{F}$. Annual cooling degree days (CDDs) are the sum of the degree days over a calendar year.

- Heating degree day base 65F (HDD65). For any 1 day, when the mean temperature is less than $65^{\circ} \mathrm{F}$, there are as many degree days as degrees Fahrenheit temperature difference between the mean temperature for the day and $65^{\circ} \mathrm{F}$. Annual heating degree days (CDDs) are the sum of the degree days over a calendar year.

Mean monthly temperature was then inserted into the CDD65 and HDD65 formulas to calculate mean monthly CDD65 and HDD65. Any negative value was changed to zero. Mean monthly CDD65 and HDD65 were then multiplied by the number of days in the month for each month to calculate monthly CDD65 and HDD65 estimates. Finally, monthly CDD65 and HDD65 estimates were summed to calculate an annual estimate of total heating and cooling degree days for each GCM, RCP, and epoch at Fort Benning, GA.

\footnotetext{
${ }^{1} 18.3^{\circ} \mathrm{C}$
} 


\section{RESULTS}

Figure 1 shows a plot of output for Fort Benning, GA. The highest and lowest RCP scenario for each of the nine GCMs evaluated was used to estimate heating and cooling degree days for four different epochs: 2025, 2035, 2045, and 2055. As expected, the number of cooling degree days has an upward trend and the number of heating degree days has a downward trend.

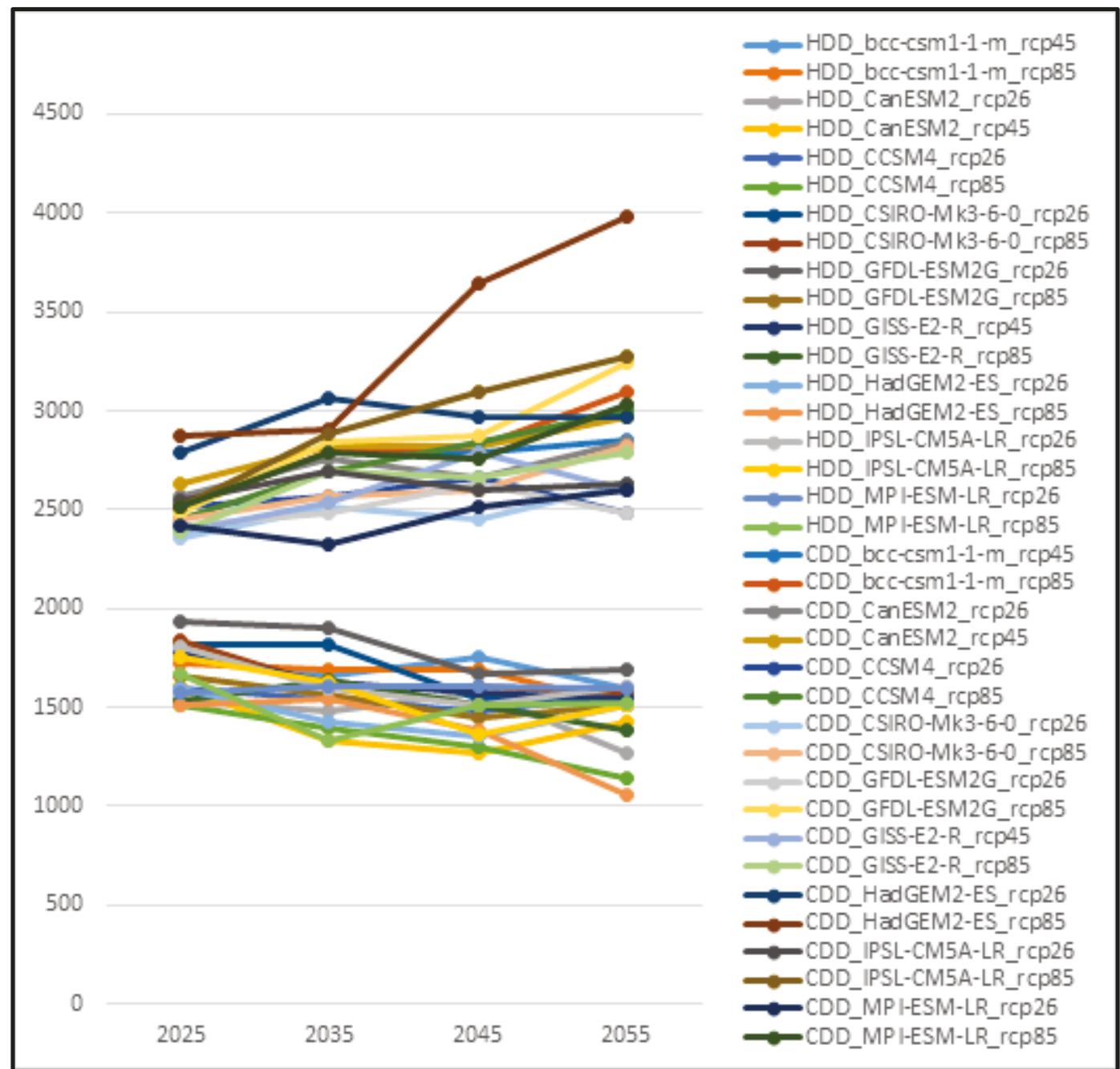

Figure 1. Projected heating and cooling degree days for nine GCM's (two RCP scenarios per GCM) and four epochs at Fort Benning, GA.

\section{SUMMARY}

Calculating heating and cooling degree days for future time periods based on projected mean temperatures from GCMs provides a rudimentary capability to estimate relative increases/decreases in heating and cooling costs on military installations. Projected mean monthly climate data $(1 / 8-$ degree BCSD-CMIP5 Climate Monthly Projections) for each of nine representative GCMs and for emission scenarios RCP2.6 and RCP8.5 were calculated CONUS-wide for four different epochs. Using the R statistical package, an automated method for calculating mean monthly temperature for the four different epochs for each GCM and RCP emission scenario was demonstrated for an 
installation case study (Fort Benning, GA). Mean monthly temperature data were then used as input to heating and cooling degree day calculations, and were summed to calculate an annual estimate of total heating and cooling degree days for each GCM, RCP, and epoch at Fort Benning, GA. The demonstrated methods could be applied CONUS-wide to estimate projected increases or decreases in heating and cooling degree days for any given location, including any DOD training installation.

\section{POINT OF CONTACT}

The point of Contact for technical inquiries for this TN is Scott A. Tweddale. Contact via email at: Scott.A.Tweddale @usace.army.mil, or by phone at: 217-3734550.

This TN should be cited as follows:

Tweddale, Scott A. 2018. Use of Heating and Cooling Degree Days To Project Relative Changes in Heating and Cooling Costs in Response to Climate Change on Selected Army Installations. ERDC/CERL TN-17-2. Champaign, IL: Engineer Research and Development Center, Construction Engineering Research Laboratory (ERDC-CERL), http://dx.doi.org/10.21079/11681/26648

\section{REFERENCES}

American Society of Heating, Refrigerating, and Air-Conditioning Engineers (ASHRAE). 2013. Energy Standard for Buildings Except Low-Rise Residential Buildings. ANSI/ASHRAE/IES Standard 90.1-2013. Atlanta, GA: ASHRAE.

Moss, R. H., J. A. Edmonds, K. A. Hibbard, M. R. Manning, S. K. Rose, D. P. van Vuuren, T. R. Carter, S. Emori, M. Kainuma, T. Kram, G. A. Meehl, J. F. B. Mitchell, N. Nakicenovic, K. Riahi, S. J. Smith, R. J. Stouffer, A. M. Thomson, J. P. Weyant and T. J. Wilbanks. 2010. "The next generation of scenarios for climate change research and assessment." Nature. 463, doi:10.1038/nature08823.

Weatherly, John W. December 2017. Projections of Climate Impacts and Extremes for CONUS Sites. ERDC/CRREL TR-16 18. Hanover, NH: U.S. Army Engineer Research and Development Center, Cold Regions Research and Engineering Laboratory (ERDC-CRREL). 
ERDC/CERL TN-17-2

NOVEMBER 2017

\section{ACRONYMS AND ABBREVIATIONS}

Term

ANSI

ASHRAE

BCC

BCSD

BRAC

CAA

CDD

CMIP

CONUS

CRREL

CSIRO

DOD

ERDC-CRREL

GCM

GFDL

GISS

IES

IPSL

LR

MPI-M

NASA

RCP

TN

TR

WCRP
Definition

American National Standards Institute

American Society of Heating, Refrigerating, and Air-Conditioning Engineers

Beijing Climate Center

Bias-Corrected Statistical Downscaling

Base Realignment and Closure

Center for Army Analysis

Cooling Degree Day

Coupled Model Intercomparison Project

Continental United States

Cold Regions Research and Engineering Laboratory

Australia's Commonwealth Scientific and Industrial Research Organization

U.S. Department of Defense

Engineer Research and Development Center, Cold Regions Research and Engineering Laboratory

Global Circulation Model

Geophysical Fluid Dynamics Laboratory

NASA Goddard Institute for Space Studies

Illuminating Engineering Society

Institut Pierre-Simon Laplace

Letter Report

Max-Planck-Institut for Meteorology

National Aeronautics and Space Administration

Representative Concentration Pathway

Technical Note

Technical Report

World Climate Research Programme

NOTE: The contents of this technical note are not to be used for advertising, publication, or promotional purposes. Citation of trade names does not constitute an official endorsement or approval of the use of such products.

Destroy when no longer needed; do not return to the originator. 